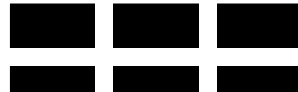 \\ THE WILLIAM DAVIDSON INSTITUTE AT THE UNIVERSITY OF MICHIGAN
}

\section{IS THE COST OF LIVING IN RUSSIA REALLY THAT LOW?}

\author{
By: Konstantin Gluschenko
}

William Davidson Institute Working Paper Number 949 December 2008 


\title{
IS THE COST OF LIVING IN RUSSIA REALLY THAT LOW?
}

\author{
Konstantin Gluschenko \\ Institute of Economics and Industrial Engineering \\ Siberian Branch of the Russian Academy of Sciences \\ pr. Lavrentieva 17, 630090 Novosibirsk, Russia \\ E-mail: glu@nsu.ru
}

\begin{abstract}
There is a widespread opinion that goods, especially foods, and services in Russia are very cheap as compared to the US. A number of Russian statistical indicators characterizing the cost of living, either directly or indirectly, seemingly corroborate this opinion. This paper demonstrates that these indicators are biased, sufficiently understating the cost of living in Russia. A comparison of Russian actual prices for foods with those in the US evidences that they are comparable. Moreover, the Russian prices are tending to catch up with the US prices.
\end{abstract}

JEL classification: $\mathrm{I} 31, \mathrm{O} 57, \mathrm{P} 22$.

Keywords: food prices, cost of living, minimum wage, subsistence level, Russia, US. 


\section{INTRODUCTION}

There is a widespread opinion that goods, especially foods, and services in Russia are very cheap as compared to the US. A number of Russian statistical indicators that either directly or indirectly characterize the cost of living seemingly corroborate this opinion. These are the minimum monthly wage, subsistence minimum (as well as the cost of staples basket used for estimating it), and average income in the top decile of the income distribution.

Indeed, taking the minimum monthly wage, one would think of it as an amount sufficient for, at least, healthy nutrition. The subsistence minimum should give an idea of the poverty threshold, while the cost of staples basket should show minimum expenses for healthy nutrition. Being converted into US dollars, all these figures are very small. At first sight, the impression of cheapness in Russia is corroborated by the income in the top 10-percent group. It is also fairly small; therefore one could conclude that if so small income provides belonging a person to the reach, then the cost of living in the country is indeed very low. However, these figures even by themselves can give rise to some doubts. In particular, comparing the minimum wage and subsistence minimum, a strange thing is seen: the former is smaller than the latter; thus, such a wage would place a person receiving it below the poverty threshold.

This paper demonstrates that all these indicators are in fact severely biased, sufficiently understating the cost of living in Russia. It discusses construction of each indicator and reveals reasons for biases. Confronting Russian actual prices for foods with those in the US, the paper shows that prices in these countries are comparable. Moreover, the Russian prices are tending to catch up with the US prices. Two periods are considered, the end of 2004 and the middle of 2008. Some indicators are

available only on the regional level. In such a case, the Novosibirsk Oblast is considered as a representative of typical Russian region, since prices and incomes here are not far from the national averages. To convert Russian monetary figures to US dollars, average monthly and quarterly exchange rates are used. They are computed as the arithmetic means of daily exchange rates drawn from the web site of the Central Bank of Russia (http://www.cbr.ru/currency_base/dynamics.asp).

The rest of the paper is organized as follows. The next section deals with the high end of the standard of living, considering the top decile of the income distribution. After that, the low end is considered in two sections; Section 3 discusses the minimum wage, and Section 4 discusses the subsistence minimum. Section 5 compares prices for some constituents of the latter (as well as prices 
for some other foods) in Russia and the US. In Section 6, dynamics of inflation in Russia and the dollar/ruble exchange rate are confronted, showing changes in the purchasing power of the US dollar in the Russian consumer market. Section 7 concludes.

\section{INCOMES OF THE TOP DECILE}

The average income in the top 10 percent of the income distribution in Russia would give an idea of a very high standard of living, so indirectly characterizing the cost of living in the country. Unfortunately, the Russian Statistical Agency, Rosstat (formerly, Goskomstat), does not publish such data regularly. Therefore, they are to be estimated from available data.

The average monthly per capita income in the 10-percent group of people with maximum incomes was equal to $\$ 292.23$ per month in the fourth quarter of 2002 (according to the Rosstat database; the figure obtained from a personal communication). To extrapolate this figure, let us assume that it rises in parallel with the population average income. In the fourth quarter of 2004, the latter was equal to $\$ 264.73$, or 182.9 percent relative to the same period of 2002 (computed from Goskomstat, 2003a, p. 391, and Rosstat, 2005a, p. 409). And so, the average monthly income in the top decile of the income distribution was crudely $\$ 534$ per capita as of the fourth quarter of 2004 . This amount is fairly small, giving the impression that the cost of living in Russia is very low (or, which is hardly probable, that the rich in Russia are in fact very poor as compared to the developed countries). However, the official figure is far from reality. The Russian official statistics sufficiently understates personal incomes, especially the high ones. The main points are as follows.

Given the large proportion of the poor in Russia, the top decile is not that of only better-offs; it can contain a significant proportion of low-income people. The intuition can be captured by a simple example. Let there be 100 people; 90 of them have zero income, and 10 have income of $\$ 3,000$. Thus, the average income in the top decile is $\$ 3,000$. Let us add 100 more people with zero income. Then the average income in the top decile falls to $\$ 1,500$. Such a phenomenon in the percentile representation of income distributions is well known to economists engaged in studies of incomes. Because of it, caution is needed in treating a highly polarized income distribution. Thus, in the case of Russia, belonging of a person to the top 10-percent income group (as it is defined by the official statistics) does not indicate per se his/her high standard of living.

Rosstat uses two kinds of data on incomes. The first one is based on reports from various sources 
and pretends to cover personal incomes of almost entire population (of Russia or a relevant region). The second kind is based on budget surveys covering a certain population sample. Rosstat does not report which kind of data it involves in calculation of the income distributions.

Regarding income data of the first kind, they are not reliable enough. One of reasons is in that because of high payroll tax many employers pay the most part of wage/salary informally, documenting much lesser amounts in bookkeeping (as well as statistical) reporting. And the higher the earnings, the larger their hidden part. According to Kurakin (2008), 21 percent of employees in Russia receive their earnings informally; the entire wage/salary is paid informally to 10 percent of employees (these data are valid for both 2004 and 2008). As Zherebin (2008) reports, different experts assert that 30 to 50 percent of income of the population avoid official accounting. Rosstat estimates the "gray" proportion of the wage and salary income of population to be 26 percent in 2005 and 21.5 percent in 2007, as Tarasova (2008) calculated. Thus, the estimates of the average income in the highest income group by the Russian official statistics are understated. For example, the Russian Center for Living Standard estimated the proportion of middle class in Russia at 9 percent, with monthly per capita income from $\$ 430$ to $\$ 970$ as of beginning of 2004 (Pelekhatskaya, 2004); and the middle class is not the most top income group.

Income data obtained through the budget surveys are reliable by themselves, but they do not represent all income classes. A household participates in the surveys for some modest fee, on a voluntary and long-term basis. As is well known, such a sample is biased towards the low-income end (since the mentioned fee is too small for better-offs; moreover, they are not inclined to disclose their incomes). If Rosstat uses the survey data to calculate the income distributions, then the actual highestincome group is not present at all in the distributions. Hence, the income in the top decile is sufficiently understated in this case as well.

It is worth noting that the indicator under consideration is becoming more reasonable over time. For example, in the second quarter of 2008, the average monthly income in the top decile was equal to $\$ 1,915.48$ per capita, $\$ 632.17$ being the population average income (computed from Rosstat, 2008e, p. 451 ; the proportion of the top decile of the income distribution in the total income is taken as of the first quarter of 2008 from Rosstat, 2008b, p. 220). Nonetheless, this amount is also severely underestimated, as numerous publications prove. 


\section{MiNIMUM WAGE}

Let us turn now to the opposite end of the welfare scale, to indicators characterizing minimal standards of living.

The Russian legislation fixes the minimum monthly wage (the exact term is "the minimum amount of labor payment"). It plays several roles. First, the minimum wage is a lower bound for wages and salaries in private institutions. Second, it serves as a base for determining salaries in state-run institutions (such as public schools, health care institutions, libraries, etc.); the salary of an employee is determined as the minimal monthly wage multiplied by a coefficient depending on employee's category. (There are 18 categories, the coefficient for employees with category 1, say, office-cleaners, equaling 1.0.) In the recent years, however, the Russian labor legislation tends to depart from such a system. Third, the minimum wage served also as a base for determining sick benefits, alimonies, fines, etc. Thus, it operated as a "monetary unit." This role was prescribed to the minimum monthly wage in 1995, the time of galloping inflation in Russia; were the above-mentioned payments denominated in rubles, they needed to be permanently changed. The "monetary-unit" role of the minimum wage was limited in 2001 (by fixing its value at a constant level for fines and some other payments), and finally abolished by the Federal Law (2007).

Unlike the US, the Russian minimum wage is not indexed routinely according to inflation rates, but is fixed from time to time by special federal laws. The reason is in that a rise in the minimum wage increases the budget burden (on the federal and regional levels) because of increasing salaries in the state-run institutions. And so, changes in the minimum wage are determined by possibilities of the state budget rather than by inflation rates. Thus, the minimum wage does not concern at all the cost of living in the country.

According to Russian government's intentions, the minimum wage should eventually come up with the minimum subsistence level, but so far it is much lower than the subsistence level. For this reason, albeit the minimum wage is indexed irregularly, the increases take the lead over inflation. Table 1 tabulates the values of the minimum monthly wage over a span of time covering that under consideration. 
Table 1. The minimum monthly wage in Russia

\begin{tabular}{|c|c|c|c|c|c|}
\hline \multirow{2}{*}{ Valid for } & \multirow{2}{*}{$\begin{array}{c}\text { Minimum } \\
\text { wage, } \\
\text { rubles }^{\text {a }}\end{array}$} & \multicolumn{2}{|c|}{ Minimum wage, $\$$} & \multicolumn{2}{|c|}{$\begin{array}{c}\text { The cost of staples } \\
\text { basket }^{\mathrm{b}}, \$\end{array}$} \\
\hline & & $\begin{array}{c}\text { At the } \\
\text { beginning }\end{array}$ & $\begin{array}{l}\text { At the } \\
\text { end }\end{array}$ & $\begin{array}{l}\text { In the first } \\
\text { month }\end{array}$ & $\begin{array}{c}\text { In the last } \\
\text { month }\end{array}$ \\
\hline October 1,2003 , to December 31, 2004 & 600.00 & 19.60 & 21.62 & 34.28 & 43.65 \\
\hline January 1,2005 , to August 31,2005 & 720.00 & 25.95 & 25.22 & 44.89 & 47.19 \\
\hline September 1, 2005, to April 30, 2006 & 800.00 & 28.01 & 29.34 & 45.74 & 54.35 \\
\hline May 1, 2006, to August 31, 2007 & $1,100.00$ & 40.34 & 42.88 & 55.65 & 64.76 \\
\hline Since September 1, 2007 & $2,300.00$ & 89.74 & $98.04^{\mathrm{c}}$ & 64.74 & $91.96^{\mathrm{d}}$ \\
\hline
\end{tabular}

a Sources: Federal Law (2003, 2005, 2007).

b Sources: Goskomstat (2003b, p. 377) and Rosstat (2004, p. 370; 2005a, p. 393; 2005b, p. 397; 2005 c, p. 387; 2006b, p. 399; 2006c, p. 377; 2007a, p. 398; 2007b, p. 424; 2008d, p. 411).

${ }^{\mathrm{c}}$ As of June 30, 2008.

${ }^{\mathrm{d}}$ For June 2008.

In addition to the amounts of the minimum monthly wage, Table 1 compares them with the cost of staples basket (the country weighted average). This comparison evidences that not only the minimum wage is lower than the subsistence minimum. Strikingly, it does not suffice (except for the amount in June 2008) even for purchase of the staples basket, so dooming a recipient to starvation. This fact along with the above considerations suggests that the minimum monthly wage is improper indicator for judging the cost of living in Russia.

\section{SUBSISTENCE MINIMUM AND THE STAPLES BASKET}

The Presidential Decree (1992) defined two indicators of the minimal living standard. The first one is a minimum consumer budget. It was intended for build-up of long-term socio-economic policy. There is no information whether this indicator was actually used for this purpose. It seems that it was not (and still is not). Anyway, the minimum consumer budget did not find wide application and was not considered as an official statistical indicator. Curiously, it is little known even to Russian economists. This may be a reason why many Russian regional governments stopped calculating the minimum consumer budgets by now, although they had calculate them during some time after the mentioned Decree. The second indicator is a subsistence (physiological) minimum. According to the Presidential Decree (1992), it was meant to be temporary, for the period of overcoming the crisis situation in the Russian economy, after which the subsistence minimum should have been ousted by the minimum consumer budget. Albeit that crisis situation is over, the latter indicator is almost 
forgotten, while the former one (having lost the attribute "physiological") is extensively used, widely known, and regularly published in statistical bulletins and yearbooks.

Until 2000, the subsistence minimum was determined on the federal level. Its base was the cost of staples basket. Expenditures for manufactured goods and services were estimated as a fixed percentage ( 40 percent) of the cost of staples basket. The staples basket varied over time: it included 19 foods in 1992-1996, and 25 foods from January 1997 through June 2000. Since July 2000, the basket consists of 33 foods. In 2000, the methodology of determining the subsistence minimum changed. Determination of the subsistence minimums was delegated to regional governments. This indicator is calculated quarterly and is approved by a governor decree. In addition to the staples basket, specific manufactured goods and services are taken into account instead of crude estimate of total expenses for them. Nonetheless, the methodology is common for all subjects of the Russian Federation, the staples basket being uniform across regions.

Judging from sums that would provide thrifty subsistence in general and frugal meal in particular, it seems that goods and services in Russia are very cheap. Indeed, in the Novosibirsk Oblast in 2004 , the subsistence minimum for the fourth quarter was $\$ 98.74$ per month for a working age person; and the monthly cost of the staples basket was $\$ 42.72$ in December (Rosstat, 2005a, p. 418; 2004 , p. 371). In 2008 , the regional subsistence minimum was $\$ 222.05$ in the second quarter, the cost of the staples basket equaling $\$ 96.27$ in June (Rosstat, 2008d, p. 460; 2008b, p. 411). Thus, one as if could modestly live, spending \$100 per month in 2004 and \$220 in 2008, of which amounts about a half (supposedly) provides thrifty yet healthful nutrition. But with such expenditures, it is in fact possible only to live from hand to mouth

The impression of cheapness is due to that the Russian staples basket (as well as the set of other goods and services in the subsistence minimum basket) is a basket for beggars, and not even for the poor. It is readily seen from Table 2 that compares the market basket of the US Department of Agriculture Thrifty Food Plan (TFP) with the Russian staples basket (SB). In the former, the original quantities of pounds per week are converted to pounds per month by multiplication by $4 \frac{1}{3}$; in the latter, quantities are converted from kilograms to pounds to correspond (the weight of one egg is taken as 70 grams). It is worth noting that the Thrifty Food Plan was updated in 2006 (the monthly cost of the relevant market basket equaling $\$ 169.30$ in June 2008, according to US Department of Agriculture, 2008), while the Russian staples basket is still valid. 
Table 2. Comparison of US and Russian minimal food baskets

\begin{tabular}{|c|c|c|c|}
\hline \multicolumn{2}{|c|}{$\begin{array}{l}\text { Market Basket of the Thrifty Food Plan, male 20-50, } \\
\text { US }^{\mathrm{a}}\end{array}$} & \multicolumn{2}{|c|}{$\begin{array}{c}\text { Basket of } 33 \text { staples, male of working age, } \\
\text { Russia }^{b}\end{array}$} \\
\hline Food category & $\begin{array}{c}\text { Pounds per } \\
\text { month }\end{array}$ & Food category & $\begin{array}{c}\text { Pounds per } \\
\text { month }\end{array}$ \\
\hline Total pounds & 144.30 & Total pounds & 132.68 \\
\hline Grains & 20.41 & Grains & 40.73 \\
\hline Breads, yeast and quick & 5.89 & Bread, white and rye-wheat & 34.91 \\
\hline Breakfast cereals, cooked and ready to eat & 0.39 & & \\
\hline Rice and pasta & 12.39 & Rice and pasta (vermicelli) & 2.02 \\
\hline Flours & 1.52 & Wheat flour & 3.68 \\
\hline Grain-based snacks and cookies & 0.22 & Cookies & 0.13 \\
\hline Vegetables & 28.60 & Vegetables & 44.43 \\
\hline Potato products & 17.12 & Potatoes & 27.56 \\
\hline \multirow[t]{2}{*}{ Dark-green and deep-yellow vegetables } & 1.60 & Cucumbers & 0.33 \\
\hline & & Carrots & 6.43 \\
\hline \multirow[t]{2}{*}{ Other vegetables } & 9.88 & White cabbages & 6.43 \\
\hline & & Onions & 3.68 \\
\hline Fruits & 27.82 & Fruits & 3.42 \\
\hline Citrus fruits, melons, berries, and juices & 15.90 & & \\
\hline Noncitrus fruits and juices & 11.92 & Apples & 3.42 \\
\hline Milk products & 30.55 & Milk products & 22.84 \\
\hline \multirow[t]{2}{*}{ Whole milk, yogurt, and cream } & 10.70 & Whole milk & 20.21 \\
\hline & & Sour cream & 0.33 \\
\hline Lower fat and skim milk and lowfat yogurt & 18.37 & & \\
\hline Cheese & 0.87 & Cheese and cottage cheese & 2.30 \\
\hline Milk drinks and milk desserts & 0.61 & & \\
\hline Meat/meat alternates & 25.00 & Meat/meat alternates & 13.85 \\
\hline Beef, pork, veal, lamb, and game & 6.15 & Beef, pork, and lamb & 3.82 \\
\hline Chicken, turkey, and game birds & 7.45 & Chicken & 2.57 \\
\hline Fish and fish products & 2.51 & Fish, frozen and salted & 2.70 \\
\hline Bacon, sausages, and luncheon meats & 1.00 & & \\
\hline Eggs and egg mixtures & 1.65 & Eggs & 2.31 \\
\hline Dry beans, lentils, peas, and nuts & 6.24 & Peas, French beans, and millet & 2.44 \\
\hline Other foods & 11.92 & Other foods & 7.42 \\
\hline \multirow[t]{3}{*}{ Table fats, oils, and salad dressings } & 2.08 & Butter & 0.33 \\
\hline & & Margarine & 1.10 \\
\hline & & Sunflower oil & 1.29 \\
\hline Gravies, sauces, condiments, spices, and salt & 1.13 & Pepper and salt & 0.80 \\
\hline Coffee and tea & (NA) & Tea & 0.09 \\
\hline Fruit drinks, soft drinks, and ades & 8.10 & & \\
\hline \multirow[t]{2}{*}{ Sugars, sweets, and candies } & 0.61 & Sugar & 3.68 \\
\hline & & Candies & 0.13 \\
\hline
\end{tabular}

a Source: US Department of Agriculture (1999, p. 20).

${ }^{\mathrm{b}}$ Source: Government of the Russian Federation (1999). 
A low-income threshold based on the TFP is adopted as the official poverty threshold of the United States. The SB, being a basis of the subsistence minimum, serves as a similar standard in Russia. However, while the TFP is a standard for a healthful diet at a minimal cost, the food consumption suggested by the SB cannot be considered as healthful; it is rather nutrition required for survival, living death (herefrom, the former attribute "physiological"). Nevertheless, even such a low level of consumption is not currently available to a considerable number of Russians. In 2004, 17.8 percent of them had incomes less than the subsistence minimum (Rosstat, 2006, p. 205); the figure for 2007 is 13.4 percent (Rosstat, 2008c, p. 262). That is why so beggarly food basket is adopted: it allows to statistically "reduce" the extent of poverty in the country.

It is seen from Table 2 - even taking account of differences in food consumption patterns in the US and Russia - that the set of items and item quantities in the SB are insufficient for healthful nutrition. The quantities of main food categories are, for the most part, sufficiently lower in the SB than in the TFP. The exceptions are grains and vegetables, due to bread, potatoes, and some other cheap vegetables, traditional food of paupers in Russia. At the same time, the quantity of meat and poultry in the SB is less than half of that in the TFP, while because of colder climate Russians should consume them much more than Americans.

In December 2004, the monthly cost of the TFP basket presented in Table 2 was $\$ 144.00$ (US Department of Agriculture, 2004). Despite a healthful diet suggested by the TFP, it is difficult to imagine good nutrition in the US for such an amount. ${ }^{1}$ As for the above \$42.72, the December 2004 cost of SB in the Novosibirsk Oblast, this was not able to secure bearable nutrition at all.

Concluding this section, let us turn back to the mentioned minimum consumer budget. It seems much more reasonable indicator of the lower limit of welfare in a region, i.e. the actual poverty threshold. The minimum consumer budget in the Novosibirsk Oblast was equal to $\$ 254.23$ per month per head in December 2004 and $\$ 488.96$ in June 2008, of which $\$ 78.22$ and $\$ 144.20$, correspondingly, were expenses for foods (Department of Labor and Employment, Novosibirsk Oblast Government, 2004, 2008). These costs are crudely half as much as the costs of the staples basket; the latter figure is close to the cost of the TFP basket (recall, \$169,30). The minimum consumer budget for the urban population of the Novosibirsk Oblast is higher, amounting to $\$ 283,45$ in December 2004 and $\$ 551.82$

\footnotetext{
${ }^{1}$ I base this assertion on my own experience. When I lived some time in 2003 in Pittsburgh, PA, Americans told me that food expenditures of a thrifty family amounted to about $\$ 300$ per month per person. Maybe, I was not so thrifty, but I spent circa $\$ 400$ to $\$ 450$ per month for food.
} 
in June 2008.

\section{PRICES}

The best way of confronting expenditure for the US and Russian minimal food baskets would be to compute the cost of the SB in US prices, and the cost of the TFP basket in Russian prices. Unfortunately, this way is not available, lacking data on prices for all items in both Russian and US baskets. It is possible to compare prices for selected foods only. Table 3 tabulates these data (in the Russian data, the units of measure are converted to those used in the American data sources).

Table 3. Comparison of prices for foods from the Russian staples basket with US prices (in dollars per pound, except as indicated; NA = Not available)

\begin{tabular}{|c|c|c|c|c|c|c|c|}
\hline \multirow{2}{*}{ Food item } & \multicolumn{4}{|c|}{ 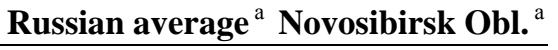 } & \multirow{2}{*}{ Food item } & \multicolumn{2}{|c|}{ US city average } \\
\hline & 2004:12 & 2008:6 & 2004:12 & 2008:6 & & 2004:12 ${ }^{\mathrm{b}}$ & 2008:6 ${ }^{\mathrm{c}}$ \\
\hline Flour, wheat & 0.21 & 0.42 & 0.19 & 0.42 & Flour, white, all purpose & 0.29 & 0.53 \\
\hline Rice, polished & 0.34 & 0.78 & 0.35 & 0.90 & Rice, white, large grain, raw & 0.57 & 0.75 \\
\hline Vermicelli & 0.37 & 0.76 & 0.35 & 0.75 & Spaghetti and macaroni & 0.95 & 1.12 \\
\hline $\begin{array}{l}\text { Bread and rolls and buns } \\
\text { from wheat flour of grades A } \\
\text { and B }\end{array}$ & 0.27 & 0.51 & 0.24 & 0.56 & Bread, white, pan & 0.97 & 1.37 \\
\hline Beef, except for boneless & 1.52 & 2.94 & 1.55 & 2.85 & Round steak, USDA Choice & 4.26 & 4.28 \\
\hline Pork, except for boneless & 1.79 & 3.18 & 1.74 & 2.98 & Pork chops, center cut, bone-in & 2.89 & 3.48 \\
\hline Chicken & 1.14 & 1.71 & 1.14 & 1.81 & Chicken, fresh, whole & 1.03 & 1.18 \\
\hline Sausage, boiled-and-smoked & 2.24 & 3.69 & 2.18 & 3.57 & Bologna & (NA) & 2.52 \\
\hline Eggs (per dozen) & 1.22 & 1.61 & 1.12 & 1.51 & Eggs, grade A, large (per dozen) & 1.20 & 1.92 \\
\hline $\begin{array}{l}\text { Milk, whole, non-sterile, } \\
\text { unbottled (per gallon) }\end{array}$ & 1.80 & 3.44 & 1.49 & 2.96 & $\begin{array}{l}\text { Milk, fresh, whole, fortified (per } \\
\text { gallon) }\end{array}$ & 3.23 & 3.77 \\
\hline Butter & 1.53 & 3.21 & 1.40 & 3.12 & Butter, salted, grade AA, stick & 3.46 & $3.26^{\mathrm{d}}$ \\
\hline Cheese, hard and soft & 1.99 & 4.13 & 2.12 & 4.34 & American processed cheese & 3.94 & 3.93 \\
\hline Apples & 0.55 & 1.20 & 0.73 & 1.27 & Apples, Red Delicious & 0.95 & 1.36 \\
\hline Potatoes & 0.13 & 0.43 & 0.10 & 0.42 & Potatoes, white & 0.51 & 0.60 \\
\hline Cabbage, white, fresh & 0.13 & 0.54 & 0.15 & 0.58 & Cabbage & (NA) & 0.67 \\
\hline Carrots & 0.18 & 0.74 & 0.18 & 0.66 & $\begin{array}{l}\text { Carrots, short trimmed and } \\
\text { topped }\end{array}$ & (NA) & 0.87 \\
\hline Peas and French beans, dried & 0.23 & 0.57 & 0.24 & 0.68 & Beans, dried, any type, all sizes & (NA) & 1.21 \\
\hline Sugar, white & 0.32 & 0.49 & 0.33 & 0.56 & Sugar, white, all sizes & 0.43 & 0.53 \\
\hline Margarine & 0.67 & 1.25 & 0.66 & 1.42 & Margarine, stick & 0.91 & 1.15 \\
\hline Sunflower oil & 0.64 & 1.47 & 0.67 & 1.53 & Shortening, vegetable oil blends & 1.29 & (NA) \\
\hline
\end{tabular}


Table 3 contains items that are more or less comparable between Russia and the US. However, the comparability is far from complete. The Russian staples basket contains a number of products with sufficiently lower quality than corresponding American ones. In particular, this concerns meat, sausage, milk, and cheese. Table 4 provides information on a few the same Russian products of higher, more comparable quality as well as on some additional foods (note that a few of them, e.g., alcoholic beverages, do not appear in the TFP basket).

Table 4. Comparison of Russian and US prices for selected foods ${ }^{\mathrm{a}}$ (in dollars per pound, except as indicated; NA $=$ Not available)

\begin{tabular}{|c|c|c|c|c|c|c|c|}
\hline \multirow{2}{*}{ Food item } & \multicolumn{2}{|c|}{ Russian average } & \multicolumn{2}{|c|}{ Novosibirsk Obl. } & \multirow{2}{*}{ Food item } & \multicolumn{2}{|c|}{ US city average } \\
\hline & 2004:12 & 2008:6 & 2004:12 & 2008:6 & & 2004:12 & 2008:6 \\
\hline Macaroni and the like & 0.40 & 0.82 & 0.47 & 0.94 & Spaghetti and macaroni & 0.95 & 1.12 \\
\hline Ground meat & 1.66 & 2.94 & 1.94 & 3.25 & Ground beef, $100 \%$ beef & 2.14 & 2.27 \\
\hline Beef, boneless & 2.30 & 4.11 & 2.30 & 3.84 & Round steak, USDA Choice & 4.26 & 4.28 \\
\hline Pork, boneless & 2.60 & 4.37 & 2.34 & 4.20 & Pork chops, center cut, bone-in & 2.89 & 3.48 \\
\hline Chicken legs & 0.99 & 1.60 & 1.07 & 1.81 & Chicken legs, bone-in & 1.37 & 1.41 \\
\hline $\begin{array}{l}\text { Canned fish, natural and with } \\
\text { oil added }\end{array}$ & 1.28 & 2.06 & 1.22 & 1.97 & Tuna, light, chunk, canned & 1.78 & (NA) \\
\hline $\begin{array}{l}\text { Milk, whole, scalded/sterile, } \\
2,5-3,2 \% \text { fat (per gallon) }\end{array}$ & 2.10 & 4.32 & 2.24 & 3.97 & $\begin{array}{l}\text { Milk, fresh, whole, fortified (per } \\
\text { gallon) }\end{array}$ & 3.23 & 3.77 \\
\hline $\begin{array}{l}\text { Ice cream }(3.75 \text { pounds } \approx 1 / 2 \\
\text { gallon })\end{array}$ & 5.29 & 9.82 & 5.63 & 14.19 & $\begin{array}{l}\text { Ice cream, prepackaged, bulk, } \\
\text { regular (1/2 gallon) }\end{array}$ & 3.85 & 4.07 \\
\hline Bananas & 0.45 & 0.75 & 0.48 & 0.74 & Bananas & 0.47 & 0.63 \\
\hline Oranges & 0.62 & 0.93 & 0.66 & 0.99 & Oranges, Navel & 0.87 & 1.14 \\
\hline Grapes & (NA) & 2.24 & (NA) & 2.61 & Grapes, Thompson Seedless & 3.09 & 2.06 \\
\hline Lemons & (NA) & 1.78 & (NA) & 2.04 & Lemons & 1.16 & 2.16 \\
\hline Pears & (NA) & 0.93 & (NA) & 0.99 & Pears, Anjou & 1.17 & 1.37 \\
\hline Tomatoes, fresh & (NA) & 1.36 & (NA) & 1.39 & Tomatoes, field grown & 2.46 & 1.81 \\
\hline $\begin{array}{l}\text { Coffee, roast, ground and } \\
\text { beans }\end{array}$ & (NA) & 7.41 & (NA) & 5.73 & $\begin{array}{l}\text { Coffee, } 100 \% \text { ground roast, all } \\
\text { sizes }\end{array}$ & 2.78 & (NA) \\
\hline $\begin{array}{l}\text { Bear (per } 16 \text { oz.), domestic } \\
\text { (above) and imported (below) }\end{array}$ & $\begin{array}{l}0.49 \\
1.54\end{array}$ & $\begin{array}{l}0.80 \\
2.54\end{array}$ & $\begin{array}{l}0.40 \\
1.40\end{array}$ & $\begin{array}{l}0.72 \\
2.80\end{array}$ & $\begin{array}{l}\text { Malt beverages, all types, all } \\
\text { sizes, any origin (per } 16 \mathrm{oz} \text {.) }\end{array}$ & (NA) & 1.15 \\
\hline $\begin{array}{l}\text { Wine, grape, dry and semidry } \\
\text { and semisweet table (per } \\
\text { liter) }\end{array}$ & 4.41 & 7.18 & 4.62 & 8.80 & $\begin{array}{l}\text { Wine, red and white table, all } \\
\text { sizes, any origin (per liter) }\end{array}$ & (NA) & 10.93 \\
\hline
\end{tabular}

${ }^{\mathrm{a}}$ The same sources of corresponding data as in Table 3.

Comparing the Russian average prices with prices in the Novosibirsk Oblast, we can see that they are, as a rule, close to one another. The same is valid for the cost of the staples basket. And so, the subsistence minimum and minimum consumer budget for the Novosibirsk Oblast can represent those for Russia as a whole.

As Tables 3 and 4 evidence, there is no great difference between prices for foods in the US and 
Russia (the more so, if one would take products of similar quality). The arithmetic means across items from both tables (excluding vermicelli, beef, pork, and milk from Table 3) suggest that foods in Russia were on average about 20 percent cheaper than in the US in the end of 2004; in June 2008, prices in Russia and the US became on average approximately equal. However, there are a few foods with much lesser prices in Russia. Bread was 3.6 times cheaper in Russia than in the US in 2004, and 2.7 times in 2008. Potatoes were 4 times cheaper in Russia in 2004, but in 2008, their price was only 30 percent lesser than in the US. Recall that bread and potatoes are foods of Russian paupers just due to traditionally low prices for them in the country; and 47 percent - by weight - of the Russian staples basket fall to their share. That is one more reason why the Russian staples basket is that cheap. (But because of dramatic rise in prices for potatoes, more than threefold from December 2004 through June 2008, even potatoes is becoming too expensive for the poor in Russia.) One more cheap food in Russia is peas and French beans that also are inferior goods in Russia. In 2008, they cost half as much as dried beans in the US; most probably, the price gap had been much wider in 2004.

Comparing 2004 and 2008 in Tables 3 and 4, it is seen that Russian prices are tending to American ones. In the end of 2004, there had been a number of products sold about half-price in Russia as compared to the US. In the middle of 2008, there were no more such foods, except for bread and peas and beans. By now, prices for many foods in Russian cities are close to those in the US. If one took products of similar quality, the Russian prices would be, in general, higher.

Unfortunately, it is impossible to compare prices for manufactured goods, since such data for the US are not available. It can be only mentioned that prices for goods of quality comparable to medium quality in the US are higher in Russia, as most of these goods are imported from abroad.

Statistical data on prices for services in the US are not available as well. However, even having got such data, one should bear in mind a few Russian features while comparing prices for services between the countries. The first one regards housing. The most part of Russians live in public apartment houses; about two thirds of apartments are privatized by now. The rent for public housing is very low; no rent is paid for privatized apartments (a real estate tax is paid instead that approximately equals the public-housing rent). But if a private apartment is rented, the rent amounts to a sum comparable to that in the US: $\$ 362$ on average over the country, and $\$ 500$ in the Novosibirsk Oblast for a one-bedroom apartment in June 2008 (Rosstat, 2008a).

The second feature regards health care. Formally, public health care is free of charge in Russia (more exactly, it is insurance medicine rather then free). However, because of poor financing, patients 
should pay informally in many cases, or buy some inventory (needed for a given kind of treatment) for physicians, such as, for example, medical gloves, syringes, etc. Certainly, the Russian official statistics does not take account of these "shadow" costs. It is worth noting that the Russian medical insurance does not cover the cost of medicines for treatment, and so, patients should buy them. Besides, the list of services provided "for free" is limited, e.g. it does not generally include high-technology services such as tomography diagnostics, etc. Moreover, the quality of public medical care and dental care is rather low; to obtain certain kinds of medical/dental care, one is put on a long waiting list. And not infrequently, this forces patients to seek private health care. Thus, the level of prices for services in Russia, be it judged on the basis of official statistical data, would turn out to be understated.

\section{INFLATION AND EXCHANGE RATE}

The opinion that the cost of living in Russia is low is a stereotype arose in 1990s and early 2000s, when goods and services in Russia were, indeed, very cheap as compared to the US (in early 1990s, even fantastically cheap). However, a few episodes apart, the general trend was in that inflation in Russia outran the US dollar/ruble exchange rate, resulting in a progressive fall of the purchasing power of dollar in the Russian consumer market.

The Central Bank of Russia started fixing of the ruble to the dollar on the base of market exchange rate (that of the Moscow Interbank Currency Exchange) since July 1, 1992. Taking indicators for July 1992 as benchmarks (100 percent), Figure 1 plots dynamics of inflation in Russia and the US dollar/ruble rate since that point in time till June 2008 (data on consumer price index, CPI, are drawn from the Socio-Economic Situation of Russia, various issues). As this figure demonstrates, the consumer price level in Russia increased in June 2008 relative to July 1992 by a factor of 1,666, while the price of dollar in Russian rubles increased by a factor of only 169. Thus, the Russian consumer prices nominated in US dollars were more and more approaching to prices in the US, becoming comparable by the middle of 2008 . 


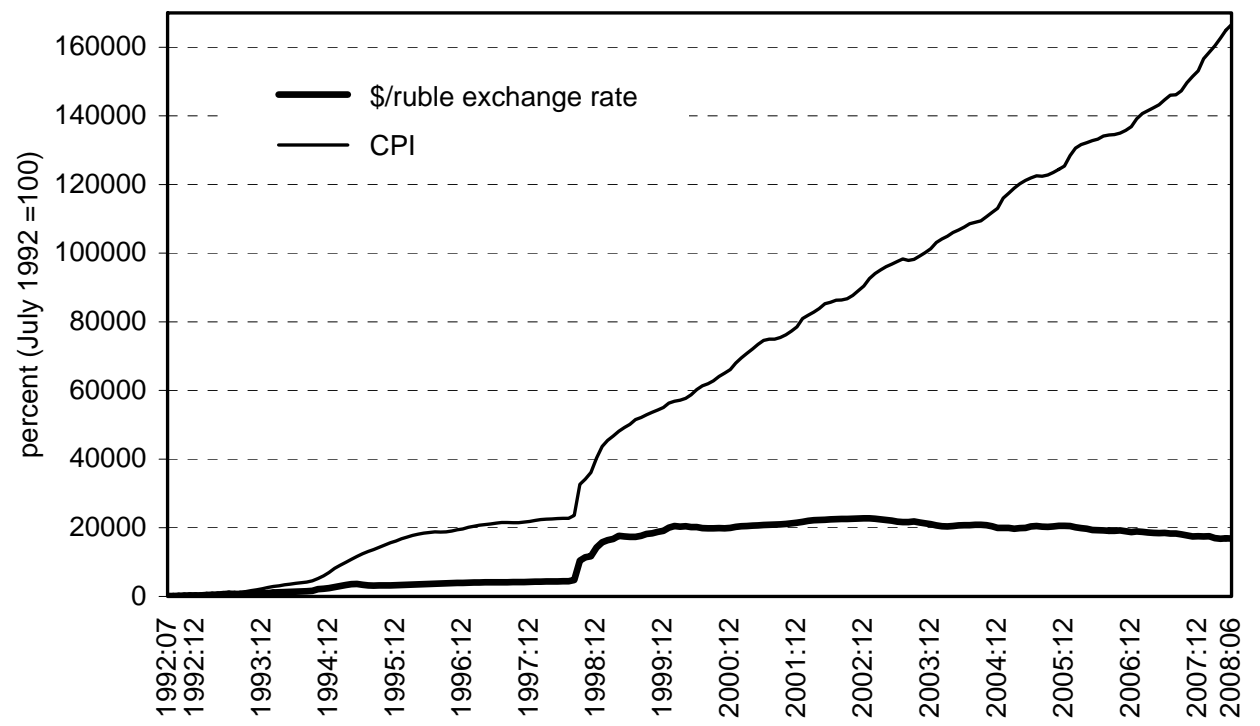

Figure 1. Russian inflation and the US dollar/ruble exchange rate

Given so great difference in rates of inflation and exchange, Figure 1 gives only general idea of their dynamics, not allowing seeing details. And so, more illustrative is deflated exchange rate (the US dollar/ruble exchange rate divided by the Russian CPI with the use of July 1992 as the base) that is depicted in Figure 2.

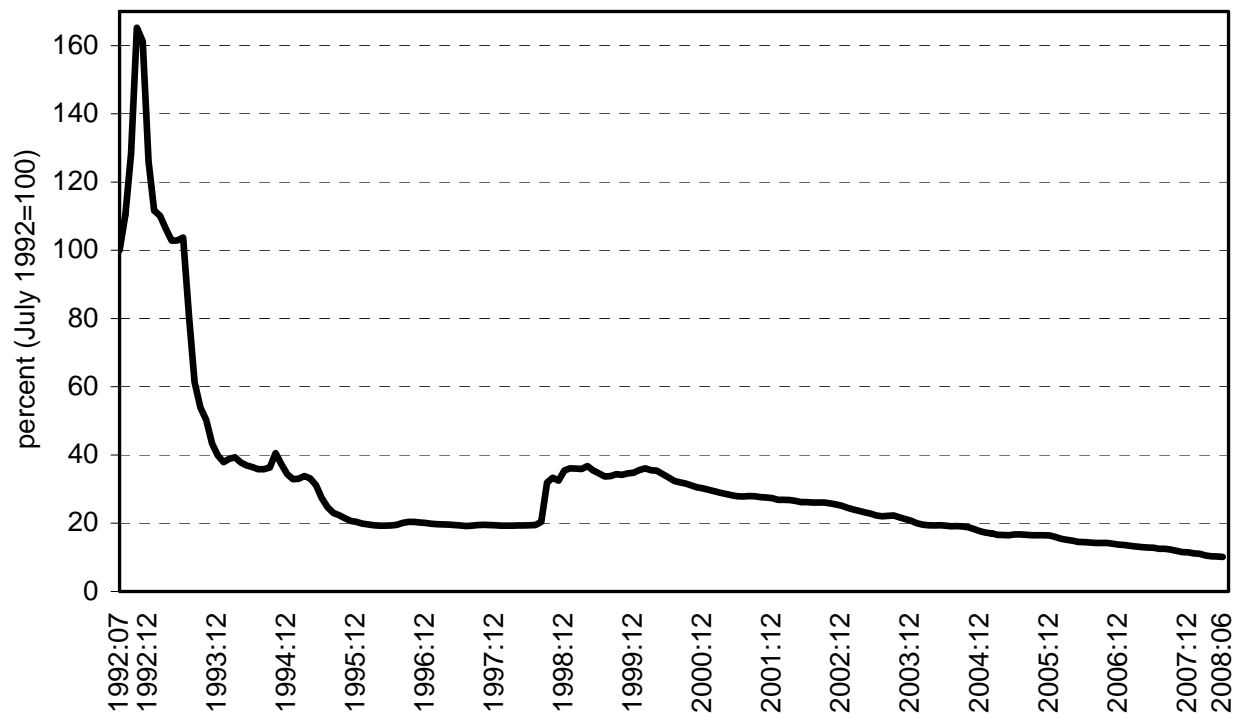

Figure 2. Purchasing power of the US dollar in the Russian consumer market

The deflated exchange rate reflects the purchasing power of the US dollar in the Russian 
consumer market as compared to July 1992. In June to November 1992, dollar went up in Russia much faster than consumer prices, its purchasing power becoming 1.6 times higher by December of that year than in July. But since December 1992, inflation overran the rise in the dollar/ruble exchange rate. As a consequence of this, dollar depreciated by the end of 1994 to about one fifth of the base level (i.e., that in July 1992). In that time, the policy of the Central Bank of Russia became to use the US dollar as an anchor. It limited fluctuations in exchange by a fairly narrow corridor, forcing the dollar/ruble rate to rise in parallel with inflation. Indeed, the purchasing power of dollar was rather stable in January 1995 through July 1998; it fluctuated between 19.3 to 20.4 percent of the base level. The overvaluation of ruble became one of the reasons of the August 1998 financial crisis in Russia. Over September 1998, the Russian ruble was devaluated 2.17-fold as compared to the previous month, so increased the purchasing power of dollar to 32 percent relative to the base. Then it rose to about 36 percent, remaining more or less stable a bit more than one year. Since March 1999, inflation again started to outrun the dollar/ruble exchange rate, this time permanently. In addition to that, the nominal exchange rate of dollar began falling since February 2003. As a result, the purchasing power of dollar returned to its pre-crisis value of about one fifth as compared to July 1992, and then fell to one tenth (to be precise, 10.1 percent) by the end of the first half of 2008 .

Thus, in June 2008, consumer prices in Russia, being nominated in US dollars, were 3-3.5 times higher than in 1999-2000, and about twice as high as in 2003. And so, the cheapness of consumer goods in Russia as compared to the US came to an end.

At last, let us consider what was going on during the time span under consideration in the above sections, December 2004 through June 2008. Figure 3 demonstrates dynamics of the US dollar/ruble exchange rate, inflation in Russia, and rise in the food price level (CPI-food) in the country relative to December 2004. It also plots the purchasing power of dollar in the Russian consumer market as a whole (exchange rate divided by CPI) and in the Russian food market (exchange rate divided by CPIfood) as compared to those in December 2004. 


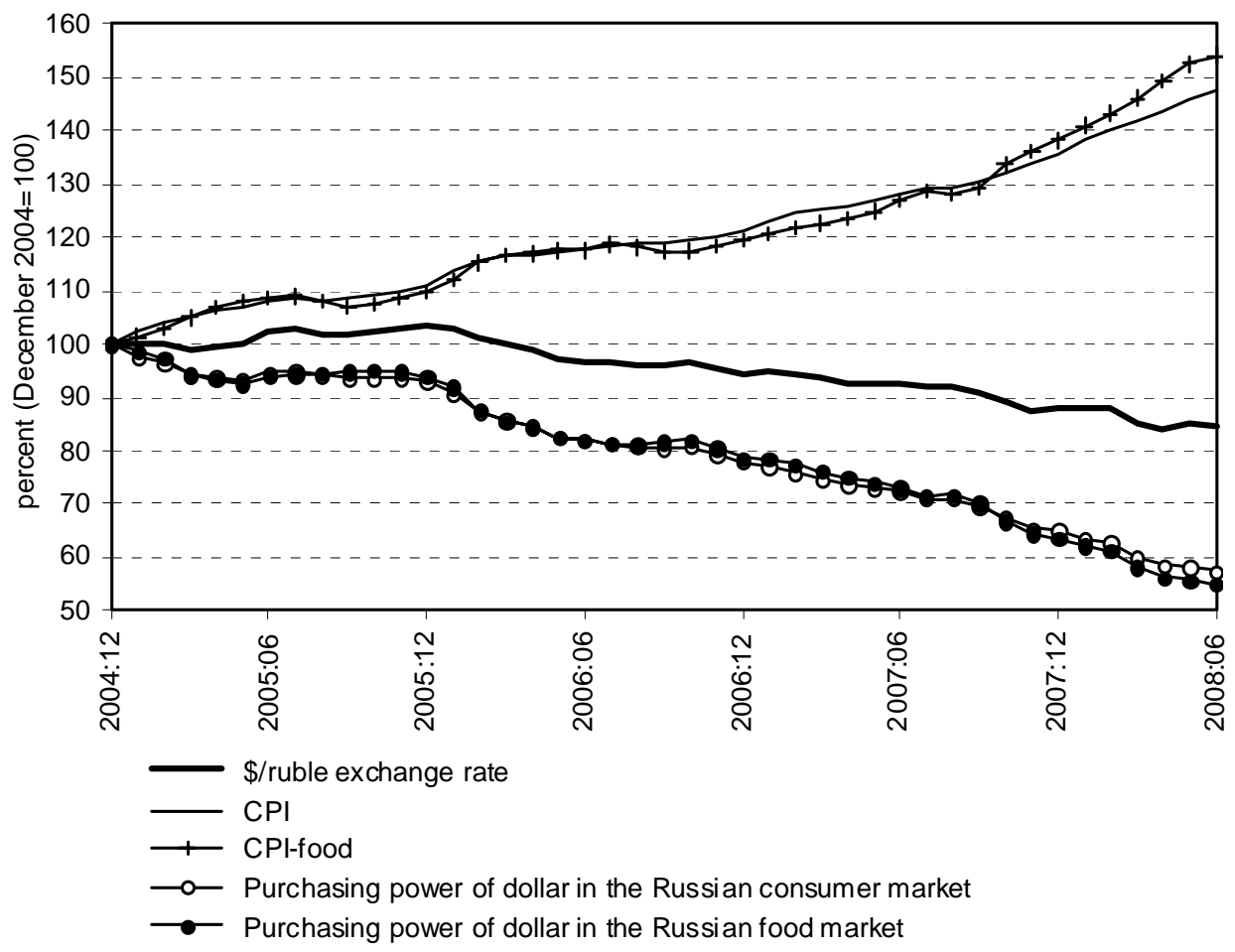

Figure 3. Changes in the dollar purchasing power from December 2004 to June 2008

As seen from Figure 3, over 3.5 years, the dollar/ruble exchange rate fell by 15.3 percent, while the consumer price level in Russia grew by 47.3 percent, and foods became more expensive by 54.2 percent. In dollars, the rise was 74 percent in the overall price level and 82.1 percent in the food price level.

It is worth adding that because of the world crisis the dollar/ruble exchange rate started fast growing since August 2008, returning in November 2008 to crudely its value in May 2006. However, this did not fundamentally change the pattern. By December 2008, the price level in Russia in dollars decreased by a bit more than 10 percent relative to June 2008. Taking it differently, the purchasing power of the US dollar in the Russian consumer market rose from 10.1 percent of the July 1992 level in June 2008 to about 11.3 percent in November 2008.

\section{CONCLUSION}

Construction of statistical indicators that could characterize the cost of living in Russia, either directly or indirectly, has been considered. The indicators discussed have been the average income in 
the top decile of the income distribution, minimum wage, subsistence minimum, and the cost of staples basket. It has been demonstrated that all these indicators are severely understated, so giving a wrong impression that the cost of living in Russia is very low relative to the US. The direct comparison of Russian and US prices for foods in December 2004 and June 2008 evidences that they are comparable. Moreover, the Russian prices are tending to catch up with the US prices.

The widespread opinion of a low cost of living in Russia was true in 1990s and early 2000s, when goods and services in Russia were, indeed, very cheap as compared to the US. As the paper has demonstrated, the consumer price level increased over 1992-2008 approximately ten times faster than the US dollar/ruble exchange rate. That is the reason why the purchasing power of dollar in the Russian consumer market decreased tenfold by the second half of 2008 relative the middle of 1992, and the cost of living in Russia became comparable with that in the US. 


\section{REFERENCES}

Bureau of Labor Statistics (2008). CPI Detailed Report. Data for June 2008. Available from: http://www.bls.gov/CPI/cpid0806.pdf

Department of Labor and Employment, Novosibirsk Oblast Government (2004). Summary table of the minimum consumer budgets for one member of a family per month with taking into account the consumer price indices. Letter of 29 December 2004, No. 1012/20-06, to local administrations. [In Russian.]

Department of Labor and Employment, Novosibirsk Oblast Government (2008). Summary table of the minimum consumer budgets for population of the Novosibirsk Oblast [online]. Available from: http://nskczn.siberia.net/_potreb.php?cat=\&id=15 [Accessed 31 July 2008; in Russian.]

Federal Law (2003). On alterations and additions to the Federal Law "On the Minimum Amount of the Labor Payment," No. 127 of 1 October. Code of Laws of the Russian Federation, No. 40, pp. 9497-9498. [In Russian.]

Federal Law (2005). On alterations to the Article 1 of the Federal Law "On the Minimum Amount of the Labor Payment," No. 198 of 29 December 2004. Code of Laws of the Russian Federation, No. 1, p. 231. [In Russian.]

Federal Law (2007). On alterations to the Federal Law "On the Minimum Amount of the Labor Payment" and other legislative acts of the Russian Federation, No. 54 of 20 April. Code of Laws of the Russian Federation, No. 17, pp. 4081-4085. [In Russian.]

Goskomstat (2003a). Socio-Economic Situation of Russia, January. Moscow. [In Russian.]

Goskomstat (2003b). Socio-Economic Situation of Russia, January-October. Moscow. [In Russian.]

Government of the Russian Federation (1999). On approval of the Methodological Recommendations for Determining Consumer Basket for the Primary Socio-Demographic Groups of the Population in Russia as a Whole and Subjects of the Russian Federation. Regulation No. 192 of 17 February. Code of Laws of the Russian Federation, No. 8, pp. 1606-1649. [In Russian.]

Kurakin, A. Wage "in envelope:" a misalliance or a marriage of convenience? Social Reality, No. 6, pp. 31-45. [In Russian.]

Pelekhatskaya, N. (2004). The Muscovites are richer than other Russians. However, provincials grow rich faster. Izvestiya, 10 September, pp. 1 and 2. [In Russian.]

Presidential Decree (1992). On the system of minimum consumer budgets for the Russian Federation population, No. 210 of 2 March. Bulletin of the Convention of the Russian Federation People's Deputies and the Supreme Council of the Russian Federation, No. 11, pp. 742-743. [In Russian.] Rosstat (2004). Socio-Economic Situation of Russia, January-December. Moscow. [In Russian.]

Rosstat (2005a). Socio-Economic Situation of Russia, January. Moscow. [In Russian.]

Rosstat (2005b). Socio-Economic Situation of Russia, January-August. Moscow. [In Russian.]

Rosstat (2005c). Socio-Economic Situation of Russia, January-September. Moscow. [In Russian.]

Rosstat (2006a). Russian Statistical Yearbook. 2005. Moscow. [In Russian.]

Rosstat (2006b). Socio-Economic Situation of Russia, January-April. Moscow. [In Russian.]

Rosstat (2006c). Socio-Economic Situation of Russia, January-May. Moscow. [In Russian.]

Rosstat (2007a). Socio-Economic Situation of Russia, January-August. Moscow. [In Russian.]

Rosstat (2008a). Average consumer prices for selected items and groups of goods and services by subject of the Russian Federation [online]. Available from:

http://www.gks.ru/scripts/db_inet/dbinet.cgi?pl=1921001 [Accessed 1 October 2008; in Russian.]

Rosstat (2007b). Socio-Economic Situation of Russia, January-September. Moscow. [In Russian.]

Rosstat (2008b). Socio-Economic Situation of Russia, January-March. Moscow. [In Russian.] 
Rosstat (2008c). Socio-Economic Situation of Russia, January-April. Moscow. [In Russian.]

Rosstat (2008d). Socio-Economic Situation of Russia, January-June. Moscow. [In Russian.]

Rosstat (2008e). Socio-Economic Situation of Russia, January-July. Moscow. [In Russian.]

Tarasova, N.A. (2008). Comparable methodology of defining indicators of the state statistics and its use in the "Population, Income, and Consumption" system. Problems of Statistics, No. 10, pp. 24-31. [In Russian.]

US Census Bureau (2008). Statistical Abstract of the United States: 2007. Washington, DC: GPO.

US Department of Agriculture (1999). Thrifty Food Plan, 1999 Administrative Report. CNPP-7. Center for Nutrition Policy and Promotion. Washington, DC.

US Department of Agriculture (2004). Official USDA Food Plans: Cost of Food at Home at Four Levels, U.S. Average, December 2004. Center for Nutrition Policy and Promotion. Available from: http://www.cnpp.usda.gov/Publications/FoodPlans/2004/CostofFoodDec04.pdf.

US Department of Agriculture (2008). Official USDA Food Plans: Cost of Food at Home at Four Levels, U.S. Average, June 2008. Center for Nutrition Policy and Promotion. Available from: http://www.cnpp.usda.gov/Publications/FoodPlans/2008/CostofFoodJun08.pdf.

Zherebin, V.M. (2008). The Russian economy and modern development trends of society. Problems of Statistics, No. 10, pp. 15-23. [In Russian.] 


\section{DAVIDSON INSTITUTE WORKING PAPER SERIES - Most Recent Papers}

The entire Working Paper Series may be downloaded free of charge at: www.wdi.umich.edu

CURRENT AS OF 2/13/09

\begin{tabular}{|c|c|c|}
\hline Publication & Authors & Date \\
\hline No. 949: IS THE COST OF LIVING IN RUSSIA REALLY THAT LOW? & Konstantin Gluschenko & Dec 2008 \\
\hline $\begin{array}{l}\text { No. 948: Banking Market Liberalization and Bank Performance: the Role } \\
\text { of Entry Modes }\end{array}$ & Ngoc-Anh Vo Thi & Jan 2009 \\
\hline $\begin{array}{l}\text { No. 947: The Monetary Union: The Decade Ahead. } \\
\text { The Case of Non-Member States }\end{array}$ & Daniel Daianu and Laurian Lungu & Jan 2009 \\
\hline No. 946: Currency Substitution: A Case Of Kazakhstan (2000:1-2007:12) & $\begin{array}{l}\text { Mesut Yilmaz, Yessengali } \\
\text { Oskenbayev \& Kanat Abdulla }\end{array}$ & Jan 2009 \\
\hline $\begin{array}{l}\text { No. 945: Determinants Of Pollution Abatement And Control Expenditure: } \\
\text { Evidence From Romania }\end{array}$ & $\begin{array}{l}\text { Guglielmo Caporale, Christophe } \\
\text { Rault, Robert Sova \& Anamaria } \\
\text { Sova }\end{array}$ & Jan 2009 \\
\hline $\begin{array}{l}\text { No. 944: Bootstrap panel Granger-causality between government } \\
\text { spending and revenue in the EU }\end{array}$ & $\begin{array}{l}\text { Antonio Afonso and Christophe } \\
\text { Rault }\end{array}$ & Jan 2009 \\
\hline No. 943: Regional Determinants of FDI Distribution in Poland & $\begin{array}{l}\text { Agnieszka Chidlow and Stephen } \\
\text { Young }\end{array}$ & Nov 2008 \\
\hline No. 942: Structural Reform and Firm Exports & $\begin{array}{l}\text { Alvaro Cuervo-Cazurra \& Luis } \\
\text { Alfonso Dau }\end{array}$ & Sept 2008 \\
\hline $\begin{array}{l}\text { No. 941: Exploring The Relationship Between Military Spending \& } \\
\text { Human Rights Performance In South Asia }\end{array}$ & $\begin{array}{l}\text { Krishna Chaitanya, Vadlamannati } \\
\text { and K K Shakya Lahiru Pathmalal }\end{array}$ & Oct 2008 \\
\hline $\begin{array}{l}\text { No. 940: Structural Reform And Firm Profitability In Developing } \\
\text { Countries }\end{array}$ & $\begin{array}{l}\text { Alvaro Cuervo-Cazurra \& Luis } \\
\text { Alfonso Dau }\end{array}$ & July 2008 \\
\hline $\begin{array}{l}\text { No. 939: Does Timing Of Elections Instigate Riots? } \\
\text { A Subnational Study Of } 16 \text { Indian States, } 1958 \text { - } 2004\end{array}$ & Krishna Chaitanya Vadlamannati & Oct 2008 \\
\hline $\begin{array}{l}\text { No. 938: Price Setting And Market Structure: An Empirical Analysis Of } \\
\text { Micro Data }\end{array}$ & Fabrizio Coricelli \& Roman Horvath & Sept 2008 \\
\hline $\begin{array}{l}\text { No. 937: Inflation Differentials in EU New Member States: An Empirical } \\
\text { Evidence }\end{array}$ & Roman Horvath \& Kamila Koprnicka & Oct 2008 \\
\hline $\begin{array}{l}\text { No. 936: Market Reforms and Growth in Post-socialist Economies: } \\
\text { Evidence from Panel Cointegration and Equilibrium Correction Model }\end{array}$ & Igor Pelipas and Alexander Chubrik & Sept 2008 \\
\hline $\begin{array}{l}\text { No. 935: Derivatives trading and the volume-volatility link in the Indian } \\
\text { Stock Market }\end{array}$ & $\begin{array}{l}\text { S. Bhaumiky, M. Karanasosy and } \\
\text { A. Kartsaklas }\end{array}$ & April 2008 \\
\hline $\begin{array}{l}\text { No. 934: Yuan Real Exchange Rate Undervaluation, 1997-2006. How } \\
\text { Much, How Often? Not Much, Not Often }\end{array}$ & $\begin{array}{l}\text { Jeff Chen, Wende Deng \& David } \\
\text { Kemme }\end{array}$ & Aug 2008 \\
\hline $\begin{array}{l}\text { No. 933: How Important Are Foreign Shocks in Small Open Economy? } \\
\text { The Case of Slovakia }\end{array}$ & $\begin{array}{l}\text { Roman Horváth and Marek } \\
\text { Rusnák }\end{array}$ & Sept 2008 \\
\hline $\begin{array}{l}\text { No. 932: Estimating Poverty for Indigenous Groups in Chile } \\
\text { by Matching Census and Survey Data }\end{array}$ & $\begin{array}{l}\text { Claudio A. Agostini, Philip H. } \\
\text { Brown, and Andrei Roman }\end{array}$ & Aug 2008 \\
\hline $\begin{array}{l}\text { No. 931: Is There Electoral Cycles In Globalization Process? Evidence } \\
\text { From } 78 \text { Democratic Countries, } 1975 \text { - } 2006\end{array}$ & Krishna Chaitanya Vadlamannati & Sept 2008 \\
\hline No. 930: Lobbying, Corruption \& Other Banes & $\begin{array}{l}\text { Nauro Campos \& Francesco } \\
\text { Giovannoni }\end{array}$ & Sept 2008 \\
\hline $\begin{array}{l}\text { No. 929: Do Elections Slow Down Economic Globalization Process In } \\
\text { India? It's Politics Stupid! }\end{array}$ & Krishna C Vadlamannati & Aug 2008 \\
\hline $\begin{array}{l}\text { No. 928: Impact Of Institutional Quality On Human Rights Abuses } \\
\text { In Transition Economies }\end{array}$ & $\begin{array}{l}\text { Krishna C Vadlamannati \& Artur } \\
\text { Tamazian }\end{array}$ & July 2008 \\
\hline $\begin{array}{l}\text { No. 927: Do Choice \& Speed Of Reforms Matter For } \\
\text { Human Rights During Transition? }\end{array}$ & Krishna Chaitanya Vadlamannati & July 2008 \\
\hline $\begin{array}{l}\text { No. 926: Socioeconomic, Institutional \& Political Determinants Of } \\
\text { Human Rights Abuses: A Subnational Study Of India, } 1993 \text { - } 2002\end{array}$ & Krishna Chaitanya Vadlamannati & July 2008 \\
\hline
\end{tabular}

